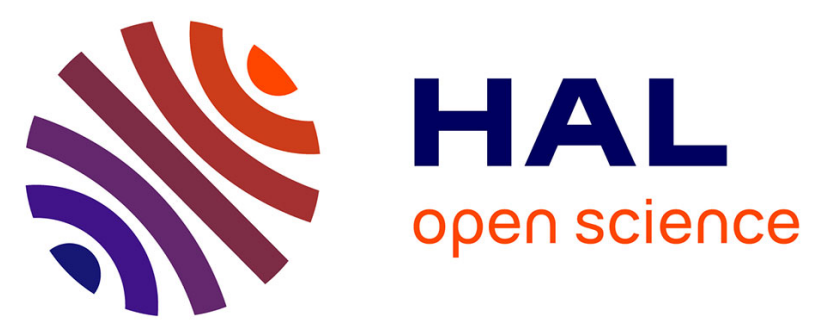

\title{
Brain abscess complicating ischemic embolic stroke in a patient with cardiac papillary fibroelastoma - Case report and literature review
}

Monique Boukobza, Sarah Nahmani, Lydia Deschamps, Jean-Pierre Laissy

\section{- To cite this version:}

Monique Boukobza, Sarah Nahmani, Lydia Deschamps, Jean-Pierre Laissy. Brain abscess complicating ischemic embolic stroke in a patient with cardiac papillary fibroelastoma - Case report and literature review. Journal of Clinical Neuroscience, 2019, 66, pp.277 - 279. 10.1016/j.jocn.2019.03.041 . hal-03487953

\section{HAL Id: hal-03487953 \\ https://hal.science/hal-03487953}

Submitted on 20 Dec 2021

HAL is a multi-disciplinary open access archive for the deposit and dissemination of scientific research documents, whether they are published or not. The documents may come from teaching and research institutions in France or abroad, or from public or private research centers.
L'archive ouverte pluridisciplinaire HAL, est destinée au dépôt et à la diffusion de documents scientifiques de niveau recherche, publiés ou non, émanant des établissements d'enseignement et de recherche français ou étrangers, des laboratoires publics ou privés.

\section{(ㅇ)(1) $\$$}

Distributed under a Creative Commons Attribution - NonCommerciall 4.0 International 
Title: Brain abscess complicating ischemic embolic stroke in a patient with cardiac papillary fibroelastoma - Case report and Literature review.

Monique Boukobza, MD, Sarah Nahmani, MD, Lydia Deschamps, MD, Jean-Pierre Laissy, $\mathrm{MD}, \mathrm{PhD}$.

Corresponding author: Monique Boukobza . Tel: + 3362465 29 32; fax: + 331402583 05. E-mail address: m.boukobza@orange.fr

Authors and affiliations:

Monique Boukobza, Department of Radiology, Assistance Publique -Hôpitaux de Paris, Bichat Hospital, 75018, Paris, France. Tel: + 336246529 32; fax: + 331402583 05. Email address: m.boukobza@orange.fr

Sarah Nahmani, Department of Radiology, Assistance Publique -Hôpitaux de Paris, Bichat Hospital, 75018, Paris, France. E-mail address: sarah.nahmani@gmail.com

Lydia Deschamps, Department of pathology, Assistance Publique -Hôpitaux de Paris, Bichat Hospital, 75018, Paris, France. Paris Diderot University, Paris, France.

E-mail address: Iydia.deschamps@aphp.fr

Jean-Pierre Laissy, Department of Radiology, Assistance Publique -Hôpitaux de Paris, Bichat Hospital, 75018, Paris, FRANCE. INSERM U1148, Paris, France; University Paris 7, Bichat Hospital, Paris, France. E-mail address: jean-pierre.laissy@aphp.fr

\section{Authors contribution:}

Monique Boukobza, MD: drafting the manuscript for content, including medical writing for content, study concept and interpretation of data, accept responsibility for conduct of research and final approval. I have no Financial Disclosure and no conflicts of interest.

Sarah Nahmani, MD: acquisition and analysis of radiological data. Accept responsibility for final approval. I have no Financial Disclosure and no conflicts of interest

Lydia Deschamps, MD: acquisition and analysis of pathological data. Accept responsibility for final approval. I have no Financial Disclosure and no conflicts of interest.

Jean-Pierre Laissy, MD, PhD: analysis and interpretation of data, critical revision of manuscript for intellectual content, accept responsibility for conduct of research and final approval. I have no Financial Disclosure and no conflicts of interest. 
Title: Brain abscess complicating ischemic embolic stroke in a patient with cardiac papillary fibroelastoma - Case report and Literature review.

Key Words: Papillary fibroelastoma; Cardio-embolic stroke; ischemic stroke; brain abscess; Mitral valve; MRI

\section{Abstract}

A 72-year-old man without obvious risk factors initially presented with acute ischemic stroke and fever, without concomitant infection. Broad spectrum antibiotic therapy was initiated. Transthoracic and Transesophageal echocardiography, and cardiac $\mathrm{MRI}$ revealed a $20 \mathrm{~mm}$ round mass attached to the anterior mitral valve leaflet, suggesting the diagnosis of a benign cardiac tumor or a vegetation. At the site of infarction an abscess of $11 \mathrm{~mm}$ in diameter developed 30 days later.

The patient underwent surgical valve repair for the prevention of further embolic complications. Histology revealed a cardiac papillary fibroelastoma (PFE). He made complete clinical recovery.

Secondary abscess formation after ischemic stroke is rare: 11 other cases have been reported. Because they develop at the site of a previous ischemic infarct, these abscesses usually do not manifest by additional neurologic deficits, making difficult their diagnosis. In most cases a concomitant infection cannot be individualized.

Even if these abscesses are a rare entity, patients with cerebral infarct presenting with fever must be closely follow-up with cerebral imaging.

Even if PFE is a rare cardiac source of embolic stroke, it should be considered in the differential diagnosis of stroke in a patient where an alternative etiology has not been established.

\section{Introduction}

Abscess formation complicating a brain infarct - not associated with endovascular procedures for ischemic strokes and decompressive hemicraniectomy - is rare and only 12 cases including ours, have been reported to date, 5 of them with MRI data (1 - 11). We report an exceptional case of ischemic embolic stroke in a patient with cardiac papillary fibroelastoma (PFE), complicated by a brain abscess at the site of 
the previous infarct and review the literature. We underline the difficulty to reach the exact diagnosis as these abscesses are often neurologically silent.

\section{Case}

A 72-year-old man without past medical history or risk factors was referred to our Hospital for the sudden onset of vertigo and right hand numbness. MRI showed small acute ischemic lesions in left cerebellum and posterior cerebral artery (PCA) territory. Repeat MRI 10 days later showed an acute infarct at the right PCA territory (Fig 1 -a); Laboratory findings did not support any acute infectious process. Electrocardiography and the 24-hour Holter ECG showed no pathological findings. There was no lesion suspicious of septic emboli on Body CT-scan. Transthoracic echocardiography (TTE), transesophageal echocardiography (TEE) and Cardiac MRI showed a mobile round mass of $20 \mathrm{~mm}$ in diameter attached to the anterior mitral valve leaflet (Fig 1-bc) and minime mitral regurgitation. The appearance was consistent with endocarditis vegetation or PFE. Post-contrast CT showed a ring-enhancing lesion at the site of the CPA infarct, highly suggestive of brain abscess on MRI (Fig. 1-d-e-f-g-h).18-FDGPET-CT did not reveal hypermetabolic focus.

Although no evident infection, and considering he had fever, he received a broadspectrum antibiotic therapy to treat a suspicious vegetation apparent on TEE (Amoxicilline 12g/d, gentamycin 240mg/d, Doxycycline $200 \mathrm{mg} / \mathrm{d}$ ). The cardiac mass was removed by surgery 10 days later, in order to reduce the risk of embolism from PFE as well as to rule out an infective endocarditis (IE) and to cure the mitral regurgitation by bioprothesis replacement. Histologic examination revealed a papillary tumor with central core of dense connective tissue surrounded by endothelial cells (Fig-1-i-j). Bacteriological analysis and cultures of the mass were negative.

Brain-CT at post-operative day 15, and day 45 showed marked regression of the described lesion. He was discharged symptom-free.

\section{Discussion}

We report a rare case of multiple cardio-embolic strokes due to PFE in a 72-year-old man without evidence of cerebro- or cardio-vascular disease. A cerebral abscess 
subsequently developed at the site of the previous larger infarct. A literature review shows only 12 cases, 5 of them being evaluated by MRI including ours, of abscesses no related to endovascular procedures for ischemic strokes or decompressive hemicraniectomy (Table 1).There was a male predominance (10/12: 83.3\%). The mean age was 57 . Because they develop at the previous stroke, these abscesses may not create additional neurologic deficits and the diagnosis may be overlooked (8). Even if stroke patients have usually associated risk factors that predispose them to brain abscess, abscess complicating brain infarct is a very rare entity. Several authors suggested that the disruption of the blood- brain barrier followed by bacteremia may predispose the affected brain tissue to infection and thus to abscess formation $(4,6,8,10)$. In only $2 / 12(16.7 \%)$, the same micro-organism was found in abscess and blood cultures.

Staphyloccocus species were the most common pathogen reported (4/8 cases with mentionned species). In most cases infections occurred during the hospitalization. For our patient the route of infection could not be detected. In all cases abscesses had a typical MRI pattern. Infarcts were localized in 10/12 cases (83.3\%) in the middle cerebral artery (MCA) territory, 2 in the PCA (5; the reported case). We evaluated subjectively the size of infarct and abscess from literature figures. In most cases abscesses developed in large infarct (8/12) and were multiple in 2 cases of large infarct. The small size of the abscess in the current case may be related to the early antibiotic treatment. The mean time interval between the diagnosis of a cerebral infarction and the detection of a brain abscess was 95.2 days (range 16-385

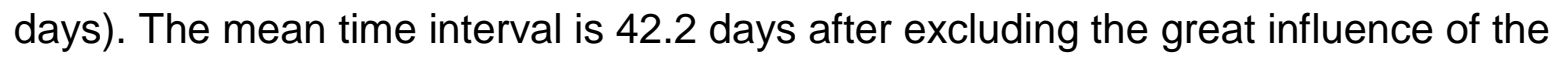
cases described by Amonn (1) and Miyazaki (7) whose abscess was diagnosed respectively 342 and 385 days after stroke. In the present case the delay was of 1 month. During the first 2 months after a stroke there is the highest risk for this complication. We can observe that the outcome was favourable in the recent years (Table 1).

Considering PFE, their clinical presentation varies from asymptomatic to embolic complications. PFE are still found incidentally at echocardiography, cardiac angiography, cardiac surgery or autopsy. On echo pattern of the cardiac tumor, other causes than PFE of a mass on the mitral leaflet such as vegetation or even thrombus were felt to be unlikely in the present clinical context. Most PFEs are solitary and small, some are mobile. However, PFE may lack some of these findings whereas 
vegetations may represent many of these characteristics (12). For that reason, PFE can often be differentiated by clinical and laboratory findings. In our case, as there was no evidence of infection or of IE, it was more likely that the lesion was PFE rather than vegetation. PFE carries very high risk of embolism because it is friable and soft, the creation of thrombi on its surface leading to stroke or transient ischemic attack, acute coronary syndrome, myocardial infarction or death from coronary ostial obstruction. A prompt surgical resection is recommended especially in case of symptomatic PFE. The long-term postoperative prognosis is excellent.

\section{Conclusion}

Patients with cerebral infarct presenting with fever must be closely follow-up with cerebral imaging.

Even if PFE is a rare cardiac source of embolic stroke, it should be considered in the differential diagnosis of stroke in a patient where an alternative etiology has not been established, especially in patients with no evidence of cerebrovascular disease, and in the presence of sinus rhythm, even in elderly.

\section{Figure Legends}

\section{Figure 1}

a: Follow-up MRI 10 days after admission: Diffusion-weighting-imaging (DWI) demonstrating an acute ischemic infarct at the right posterior cerebral artery (PCA) territory.

b- c -Transesophageal echocardiogram (b) and cardiac MRI (c) show a mobile and spherical mass of $20 \mathrm{~mm}$ in diameter attached to the anterior leaflet of the mitral valve (arrow in b).

d-- At 30 days of onset, post-contrast Brain-CT shows a ring-enhancing lesion with a necrotic center at the site of previous infarct. MRI obtained the same day shows on FLAIR (Fluid-attenuated inversion recovery) (e) and on T2 gradient-echo $\left(\mathrm{T}^{*}\right)$ (f) images a round and well-defined mass lesion within the previous infarct. This mass shows a central hyperintensity surrounded by an hypo-intense rim of, related to the hemorrhagic capsule of the abscess. The lesion is hyperintense on Diffusion- 
weighted image (DWI) (g) with marked restriction diffusion on apparent diffusion coefficient (ADC) map (h).

i-j- Pathologic finding: -Low magnification shows a papillary tumour (Hematoxilin eosine, 5X) (i).

A higher magnification shows a lesion composed of multiple papillary villous fronds with an acellular fibro-hyalinous core covered by a few endothelial cells (Hematoxilin eosine, $50 \mathrm{X})(\mathrm{j})$.

\section{References}

1 -Amonn F, Müller U. Brain abscess--a possible complication of cerebral infarction? Schweiz Med Wochenschr. 1984; 114: 58-62.

2 -Ichimi K, Ishiguri H, Kida Y, Kinomoto T. Brain abscess following cerebral infarction: a case report. No Shinkei Geka. 1989; 17:381-5. Review.

3 -Arentoft H, Schønheyder H, Schønemann NK. Cerebral Salmonella typhimurium abscess in a patient with a stroke. Infection. 1993; 21:251-3.

4-Chen ST, Tang LM, Ro LS. Brain abscess as a complication of stroke. Stroke. 1995; 26:696-8.

5 -Shintani S, Tsuruoka S, Koumo Y, Shiigai T. Sudden "stroke-like' onset of homonymous hemianopsia due to bacterial brain abscess. J Neurol Sci. 1996; 143:190-4. Review.

6 -Beloosesky Y, Streifler JY, Eynan N, Grinblat J. Brain abscess complicating cerebral infarct. Age Ageing. 2002; 31:477-80.

7 -Miyazaki H, Ito S, Nitta Y, lino N, Shiokawa Y. Brain abscess following cerebral infarction. Acta Neurochir (Wien). 2004; 146:531-2.

8 -Kaplan M, Ozveren M, Erol F, Kaplan S, Bilge T. Brain abscess developing at the site of preceding stroke. Neurosurg Quarterly 2005; 15:104-6.

9 -Shibasaki Warabi Y, Yoshikawa H, Idezuka J Yamazaki M, Onishi Y. Cerebral infarctions and brain abscess due to Lemierre syndrome. Intern Med. 2005; 44:653-6. 
10 -Emmez H, Börcek AO, Doğulu F, Ceviker N. Ischemic stroke complicated by a brain abscess: a case report and review of the literature. Turk Neurosurg. 2007; 17:48-54. Review.

11 -García-Cid N, Pérez-Rodríguez MT, Argibay-Filgueira A, Martínez-Vázquez C. Cerebral abscess over a previous ischemic infarction. Enferm Infecc Microbiol Clin. $2014 ; 32: 60-1$.

12 - Kim SY, Park TH, Lee DY, Lee DH, Cho YR, Kim MH. Papillary fibroelastoma mimicking vegetation of the mitral valve. J. Cardiovasc Ultrasound. 2012; 4: 213-5. 


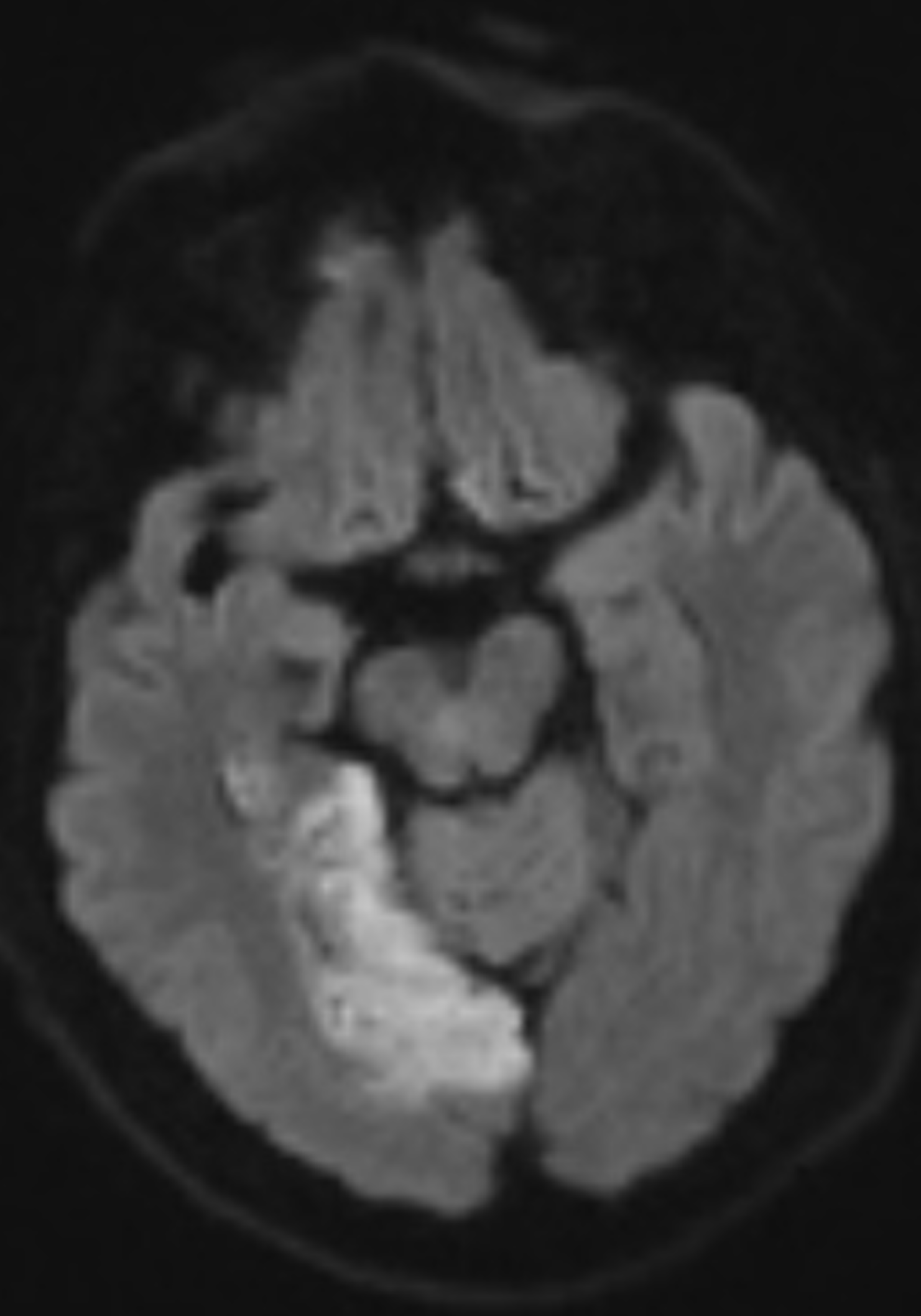




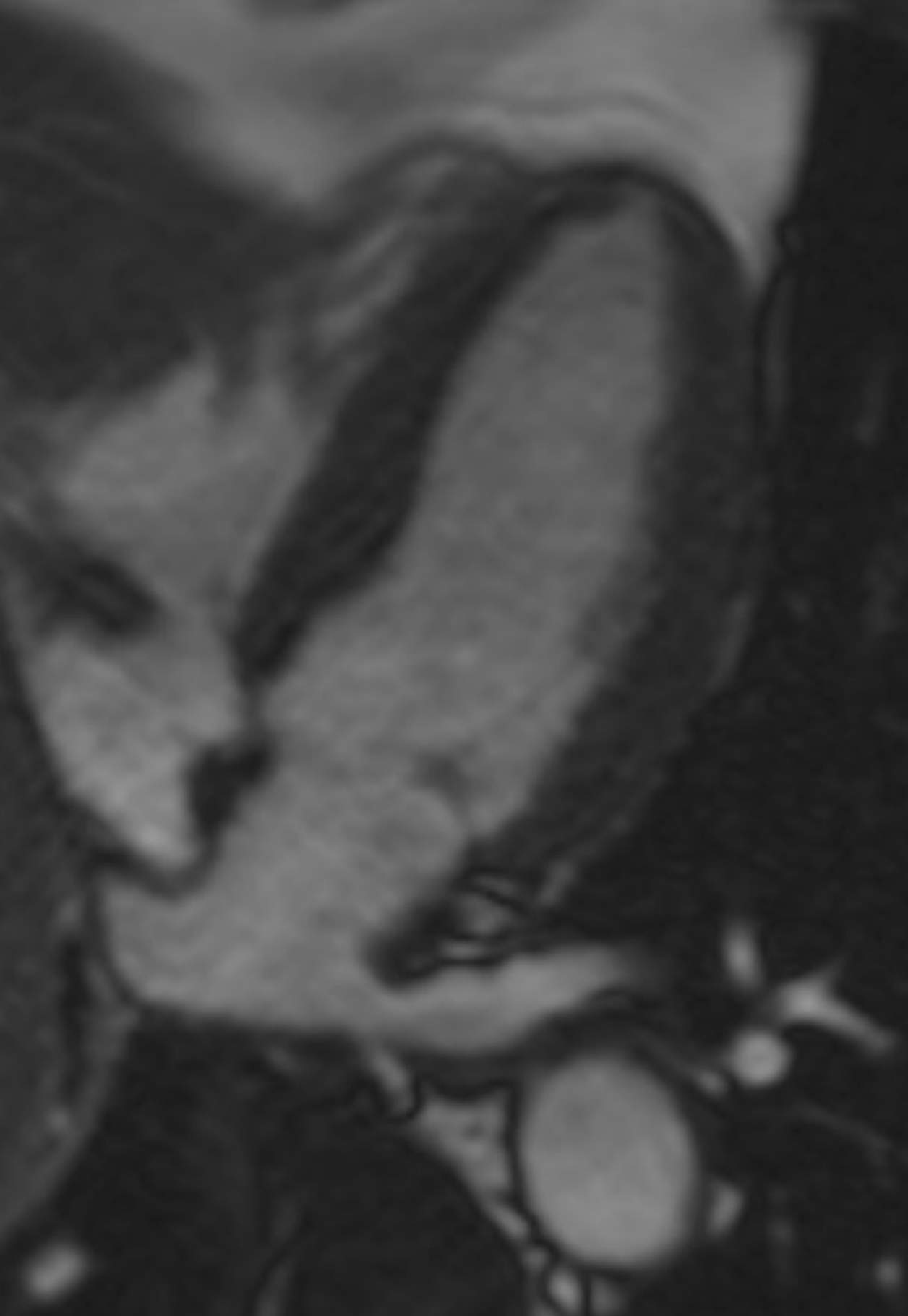




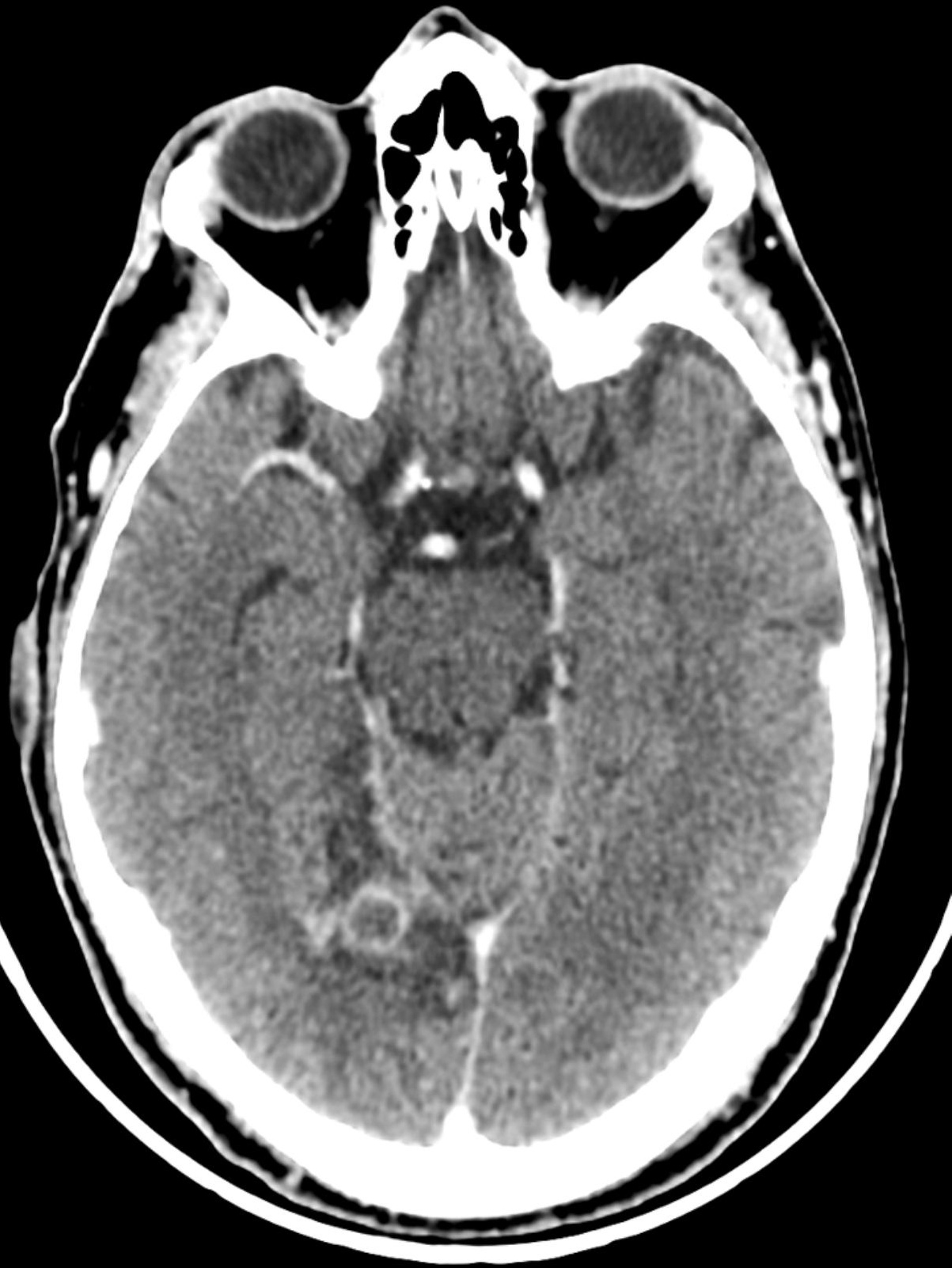




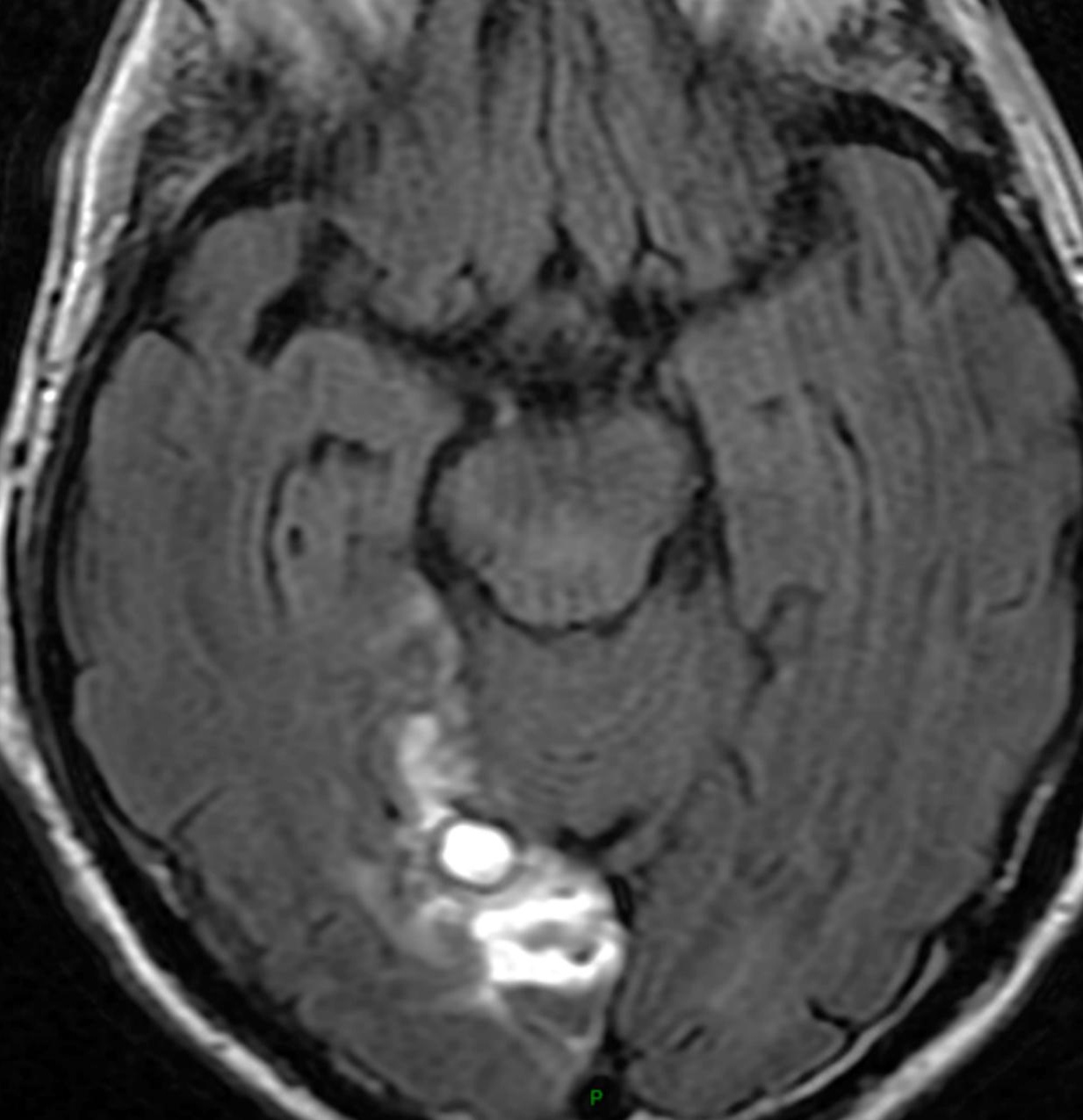




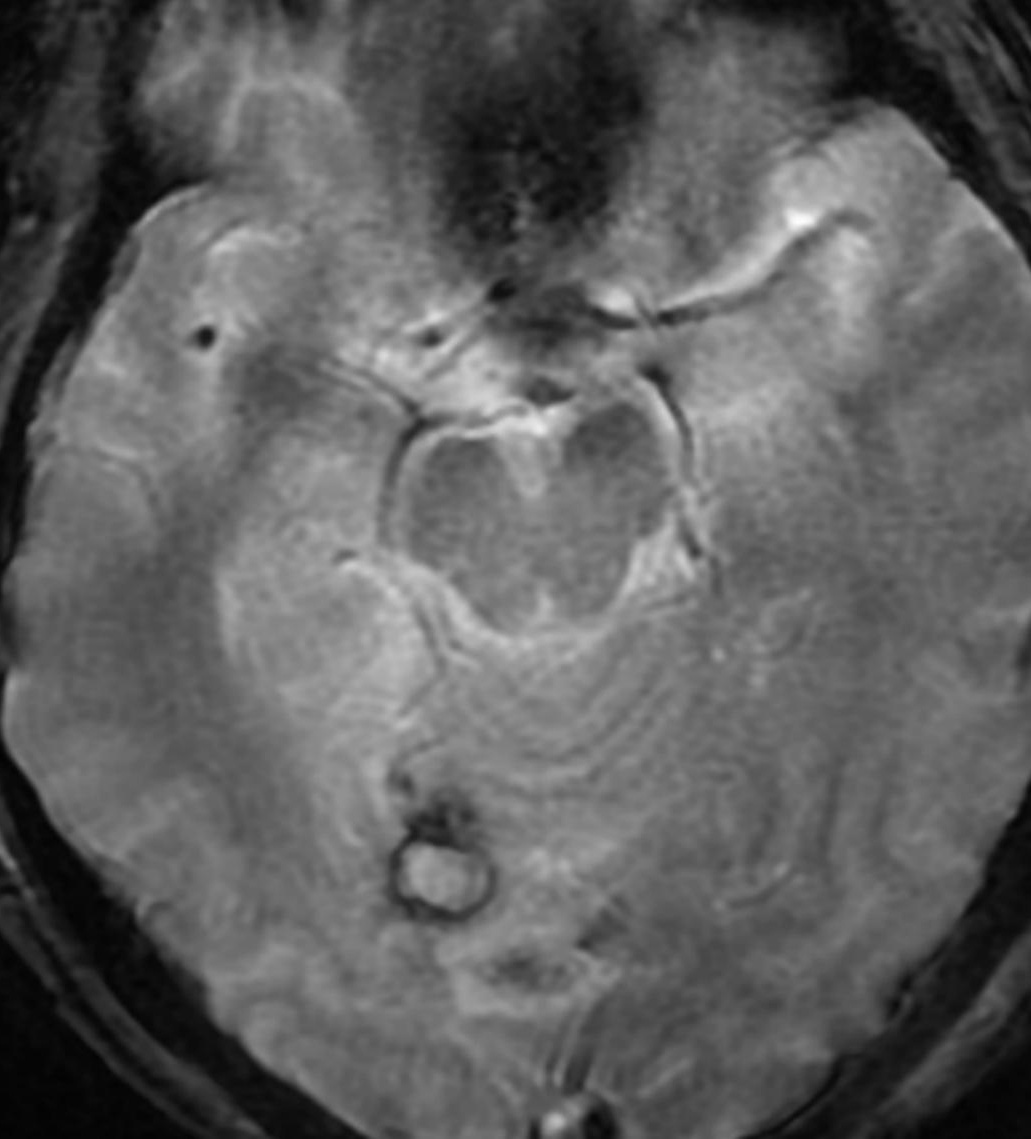




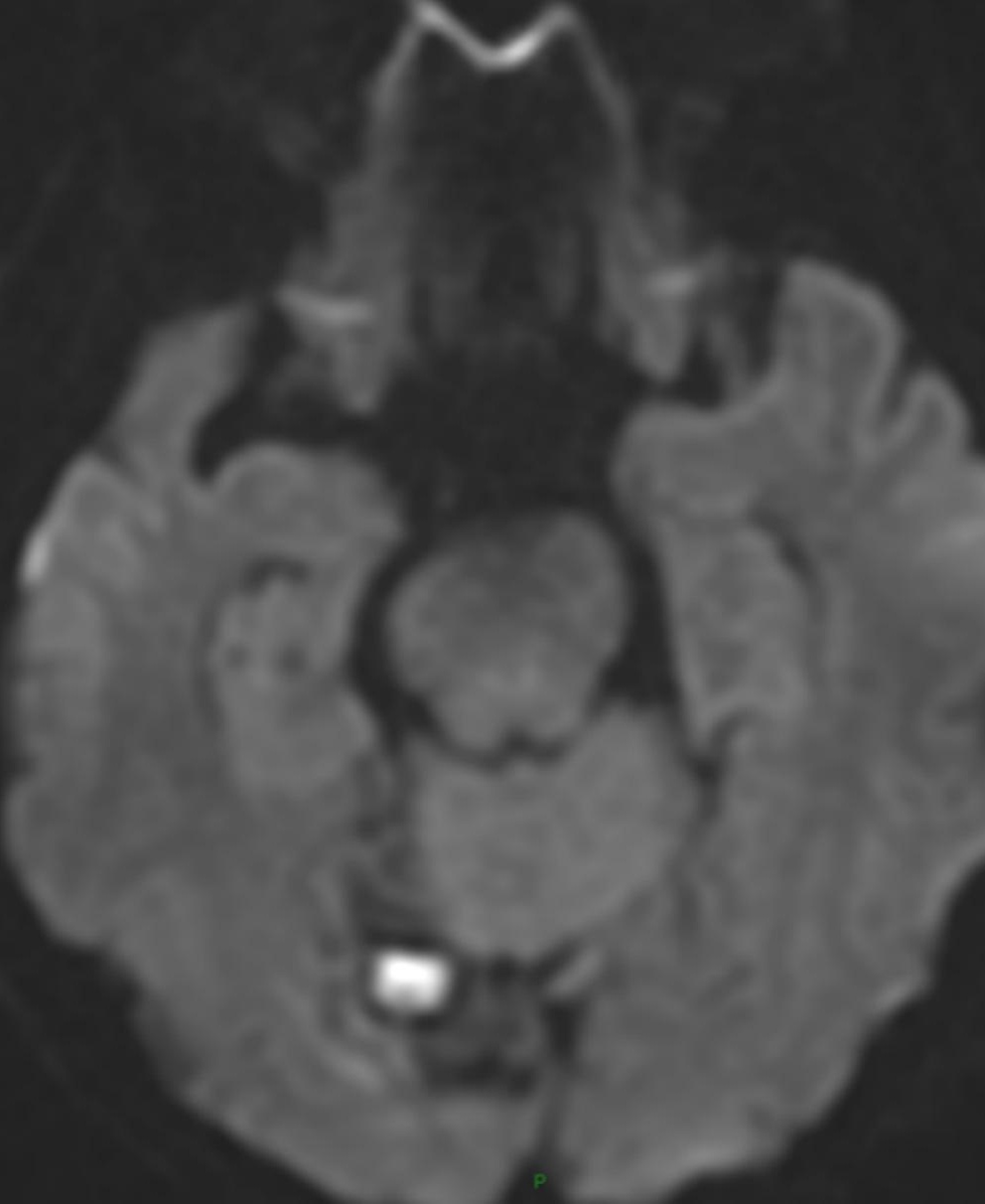




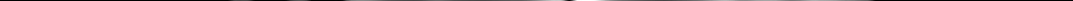




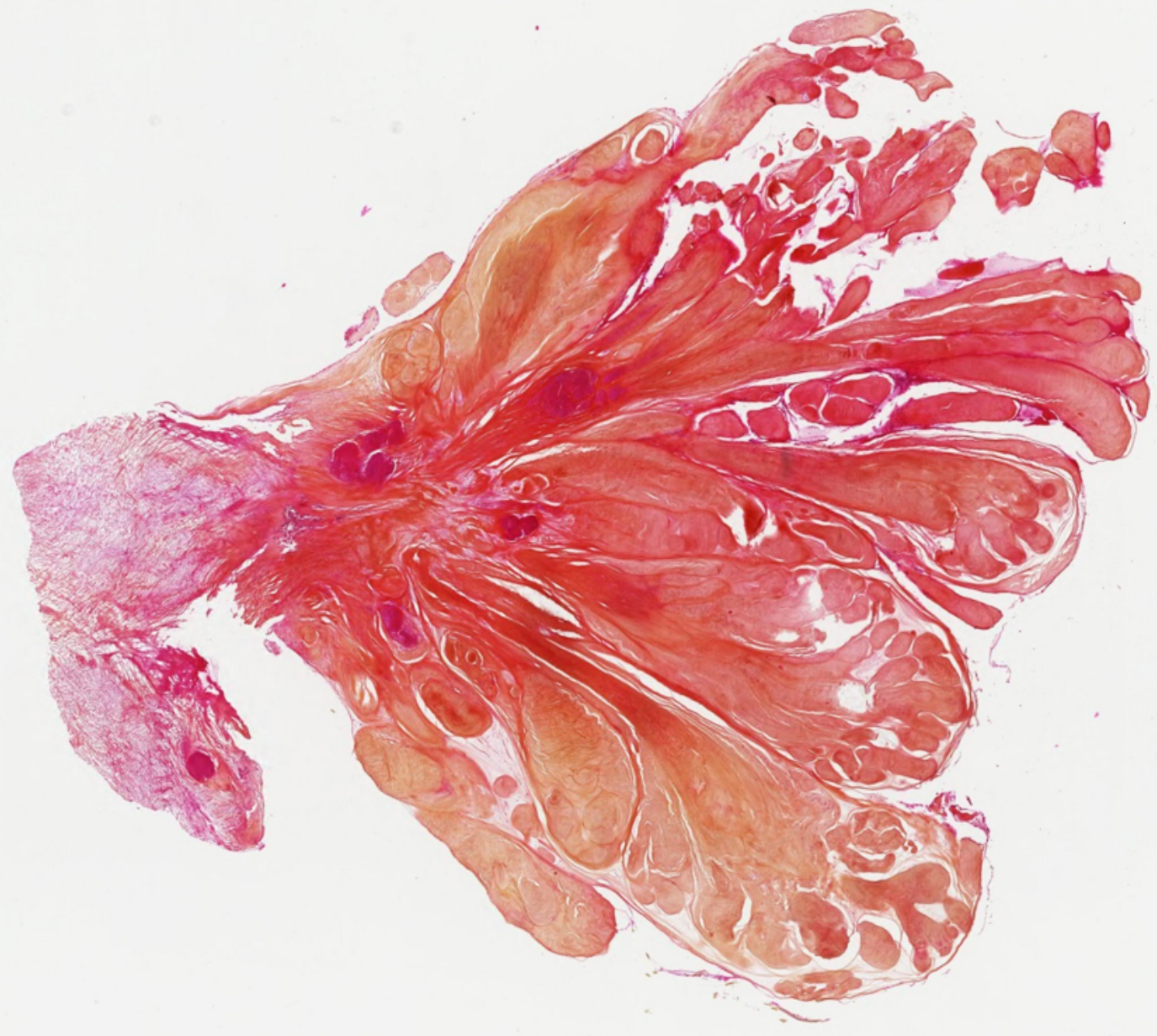




\begin{tabular}{|c|c|c|c|c|c|c|c|c|c|c|c|c|c|c|}
\hline & & Age(y) & MRI & arterial & Large & Small & Fever & Concomitant & Interval & Species & Abscess & $\begin{array}{l}\mathrm{AB} \\
\mathrm{TT}\end{array}$ & Surg & Outcome \\
\hline & Author/Year & /Sex & & territory & Infarct & Infarct & & Infection & days & & $\begin{array}{l}\text { diameter } \\
\text { (cm) }\end{array}$ & & & Outcome \\
\hline 1 & Amonn (1984) ${ }^{1}$ & $68 / M$ & & MCA (R) & $\mathrm{Y}$ & & $\mathrm{Y}$ & Bronchectasia & 342 & S. aureus & multiple & Y & & died \\
\hline 2 & Ichimi $(1989)^{2}$ & $73 / \mathrm{M}$ & & MCA (L) & $\mathrm{Y}$ & & $\mathrm{Y}$ & No & 77 & Proteus Vulgaris & multiple & $Y$ & $\mathrm{Y}$ & Favorable \\
\hline 3 & Arentoft $(1993)^{3}$ & $59 / F$ & & MCA (R) & $\mathrm{Y}$ & & $\mathrm{Y}$ & Lung & 12 & Salmonella Typhimurium & 2.5 & $Y$ & & died \\
\hline 4 & Chen $(1995)^{4}$ & $70 / \mathrm{M}$ & 1 & $\mathrm{MCA}(\mathrm{R})$ & $\mathrm{Y}$ & & $\mathrm{Y}$ & Aspiration pneumoniae & 35 & Not found & 4 & $Y$ & $\mathrm{Y}$ & died \\
\hline 5 & Shintani (1996) ${ }^{5}$ & $40 / \mathrm{M}$ & 1 & PCA (R) & $\mathrm{Y}$ & & $Y$ & No & 14 & Streptococcus & 5 & & $\mathrm{Y}$ & Favorable \\
\hline 6 & Beloosesky $(2002)^{6}$ & $68 / \mathrm{M}$ & & MCA (L) & & $\mathrm{Y}$ & $\mathrm{Y}$ & Urinary tract (Proteus mirabilis) & 84 & Proteus Mirabilis & 5 & & $\mathrm{Y}$ & died \\
\hline 7 & Miyazaki (2004) ${ }^{7}$ & $77 / \mathrm{M}$ & & MCA (L) & $\mathrm{Y}$ & & $\mathrm{Y}$ & Pneumoniae (S aureus) & 385 & S. aureus & $>10$ & $\mathrm{Y}$ & $\mathrm{Y}$ & Favorable \\
\hline 8 & Kaplan (2005) ${ }^{8}$ & $52 / \mathrm{F}$ & 1 & $\operatorname{MCA}(R)$ & $\mathrm{Y}$ & & $\mathrm{Y}$ & Pneumoniae & 56 & S. aureus & 3 & & $\mathrm{Y}$ & Favorable \\
\hline 9 & Shibasaki (2005) ${ }^{9}$ & $59 / \mathrm{M}$ & & MCA(L,deep) & & $\mathrm{Y}$ & $\mathrm{Y}$ & Temporal muscle & 16 & Not found & 1.5 & Y & & Favorable \\
\hline 10 & Emmez (2007) ${ }^{10}$ & 64/M & & MCA (L) & & Y & $\mathrm{Y}$ & No & 42 & Not found & 2 & $\mathrm{Y}$ & & Favorable \\
\hline 11 & Garcia-Cid (2014) ${ }^{11}$ & $52 / \mathrm{M}$ & 1 & $\operatorname{MCA}(R)$ & $\mathrm{Y}$ & & $\mathrm{Y}$ & No & 56 & S. Methylo Resistant & 3 & & $\mathrm{Y}$ & Favorable \\
\hline 12 & Present case (2019) & $76 / \mathrm{M}$ & 1 & PCA (R) & & $Y$ & $Y$ & No & 30 & Not found & $11 \mathrm{~mm}$ & $Y$ & & Favorable \\
\hline
\end{tabular}

Table 1: Literature cases of brain abscess complicating a cerebral infarct not associated to endovascular or surgical procedures

MRI: Magnetic resonance imaging; ABTT : Antibiotic treatment ; Surg : Surgical treatment ; M : Male ; F : Female ;NA : Not Available ; MCA: middle cerebral artery ;PCA : posterior cerebral artery ;Cerebellar a: cerebellar artery ;S. aureus : Staphylococcus aureus ;S. epidermidis: Staphylococcus epidermidis; MCA (L) Br: MCA (L) Branches; S. Methylo Resistant: Staphylococcus Methylo Resistant; P. Aeruginosa : Pseudomonas Aeruginosa.. 